\title{
電気浸透と電解の原理による土と壁体間 摩擦の軽減に関寸る実験
}

\author{
正員 浅 川 美 利* \\ REDUCTION OF SKIN-FRICTION BETWEEN SOIL AND METAL \\ WALL BY THE ELECTRO-OSMOSIS METHOD \\ By Mitoshi Asakawa,C.E. Member
}

Synopsis : If the principle of electro-osmosis is applied as a method of reducing skin friction between a metal wall and a mass of clay, the operation is simpler as compared with the conventional methods.

Moreover, this method is convenient, because the same equipment can be simultaneously used for not only reducing but also increasing the skin friction.

H.K.S.Ph. Begemann suggested already that this method could be succesefully applied to the pile-driving and the sinking of pite foundation.

But he did not present the mechanism of reducing skin friction, nor a possibility of effectively utilizing this method for various types of soil.

On the mechanism of decreasing skin friction, the author indicated that the electro physical effects consists of two reducing effects; the bubble effect due to electrolysis of water and the jetting and accumlating effects due to development of osmotic water around the negative electrode. Futhermore, the author treated experimentally the practical application of this method to the various conditions of samples.

As a general result, it has been discovered that there is a possibility of effectively utilizing this method to the foundation work in clay soil having high adhesion.

要旨 土と壁体間生ずるスキンフリクションの軽減法として電気浸透と電解の原理とが応用できる ということについて述べ，それと関する実験をいるいろな条件てつてい行い，摩擦軽減の機構や可能な 軽減量扔よび土そ対する適性などの問題について考察した。本文で述べる軽減法の特長は, ガス・バル ブ,ウォーター・ジェッティング括よびウォーター・アキュムレーションの効果を直流電気の適用のみで 同時に発揮させうることと, 加電压の調節でけで任意の軽減をはかりうることである。一方欠点として は，土と水との界面性質によつて軽減効果が変わるということと危険性があるということである。

軽減の様相としてい光ることは，直流電気を適用するとただちに軽減の效果が表われ，大抵の場合， 10 分以内で軽減可能な全効果が生ずる。またそれに達するまでの軽減速度は電圧の大きさで変わる。 本法ほ付着力の大きい粘土地盤に和ける摩擦軽減法として有効である。

\section{I. 概 要}

土と壁体間に生ずるスキンフリクションは, 地中に埋設しょうとする基礎工の実施に当つて妨げとなるもので ある。したがつてこの種の摩擦を除去あるいは軽減してやることは, 施工促進怙よび適用外力の軽減という意味 から，工事の容易さと経済性を与える。実施の方法は別として，壁体面の摩摖を軽減するには，水あるい悾気 の動的稆よび静的作用を利用して壁面と土との離縁をはかるようにするのが最も一般的な手段となつている。従 来用いられてきている方法は，その效果を機械的に与光るもので，それを単独㟧るいは複合した方式方採られて きている。本文で述べるものは, 水怙よびガスの動, 静的作用を利用してスキンフリクションを軽減しようとす ることに注わりないのであるが，その効果を機械的に外部から与变るるのではなく，土中水の電気化学的性質 そよつてそれを奏現しようとするるのである。土に直流電流を与えてスキンフリクションを軽減する原理は, 特 そ新しいるのではなく，すでそW.B. Hains ${ }^{22}$ は農業用耕作機械飞それが応用できることを指摘しているし，東 大 最上武雄教授 ${ }^{3}$ もとれ関する基本的な実験を行つている。また H.K.S.Ph. Begemann ${ }^{4}$ は現場実験とよつ

*日本大学講師, 理工学部土木教室 
て，杭の打込みやピット基礎にとれが十分応用できることそ報告している。しかしどの論文も実用できることの みを指摘しているにとどまり, 軽減の機構や土による適性の問題などには触れていない。土中水の移動あるいは 電解を利用する本法の実施では，土の界面問題をよりよく拕明されて招らなければ，実用性を拡張できない。筆 者は, 独自の立場からとれを研究し, 主としてウエルの沈設やパイプの押し込み, 矢板の引き抜きなどの実施沉 本法を適用していこうとして，小規模な模型実験や軽減機構を知るための基礎実験を行つた。ここで述べるもの はいまだ理想条件下の実験という域を出たものではないが, 摩摖軽減の様相, 土や水の物理化学的性質が軽減効 果に怙よぼす影響招よび土の鉱物的性質や粒度が異なればどんなにその軽減の状況が変つてくるかの問題を一応 検討することはできた。

結論として次のようなことが述べられる：

（1）土中に直流電流を加電すると, 土中水は電気浸透の原理にもとついて, 一方向に強制された移動を起こ す。一方電極面では, 水の電解のためにガスの発生が浸透々同侍に起こる。この雨作用を, 摩擦軽減すべき壁面 にて起させしめると，スキンフリクションの除去は，直流雪流を適用することだけで実現できることになる。

(2) 直流電流を与兄た下でのスキンフリクション軽減効果は, 電気浸透度と電解ガスの発生度とに左右され るわけであるから，これらの能力を支配する原因が，軽減度を変光ることになる。い未土と水の性質を一定とみな して上述のことを考光ると,加電压の大小が浸透秥よび電解の主要な支配因子となるので, この加電圧を調節すれ ば軽減度が時間的に変わることになる。れい埋設物沈設中の速度を加電調節の及で制御できることを意味する。

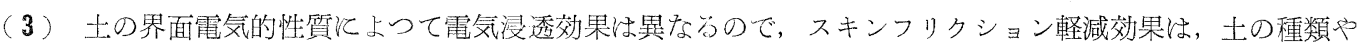
唯積条件で変つてくる 解の効果はそれぞれの支配因子が本質的に異なるわのであかから, 浸透の効果が減じても電解効果が反対増す 場合もめり，結果として一効果が減じても必ずしも全効果を減じてしまうということにはならない(これは本法 適用の範囲が拡張され，土に対する選択性を縮める意味で重要なるのである)。

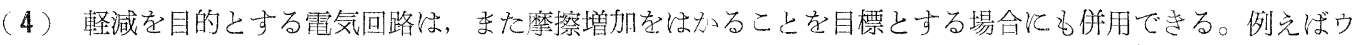
エル沈設後のスキンフリクション増加を同じ回路ではかりらる。さらにこの操作の実施は, 周辺土の脱水によつ

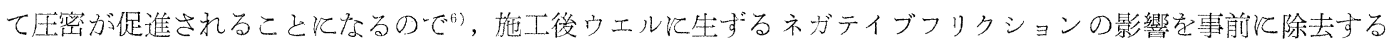
こともできよう。

（5）本法は付着力の大きい粘性土に対して有效で，秒路よび仯磁土では効果的でない。適用可能な地盤では 加電後まもなく効果が現われ，10 分間以内で軽減の全効果を発揮しうる。軟弱な粘性土では，適当な電圧を与 えるとほとんど 100\% の軽減が可能で，一般の土でも70 90\% の軽減が期待できる。

\section{II. 原 理}

概要で述べたように直流電場下では, 土中水は一方向に強制された流動を起こす性質がある（これは電気浸透 の原理によるもので，一般に土中水は陰極に问かつて流動する。いるこの流動が Holmholtz の理論によるもの と仮定すると，その浸透速度は $V_{e}=k_{e} \bullet i_{e}$ で表わされる。


動電位， $\eta$ : 水の粘性係数招よび $e$ : 土の間ゲキ比)。一方水に直流電流が与兄られると水は電解され, 水の浸透方 向すなわち陰極側とついてこれを考えると $\mathrm{H}_{2}$ ガスが電極面沉て発生する $\left(2 \mathrm{H}_{2} \mathrm{O} \rightleftharpoons 2 \hat{\mathrm{H}_{2}}{ }^{(+)}+\mathrm{O}_{2}{ }^{(-)}\right)$。これら二つ の現象は通電によつて同時に起こるわけであるから, スキンフリクションを軽減しょうとする壁面を陰極になる 上ろにすると, 浸透水の浸透作用と集水とよる潤滑作用拉上び電解ガスの泡立ち作用がその面で合成されて起こ る。これらの作用がフリクションを除去する効果であらう上考光られるもので, 表一1 亿示するのは個々の現象 あるい恔果影響すると思われるいるいろの因子を分類してみたるのである。

\section{III. スキンフリクションとそれの軽減機構を知るための予備実験}

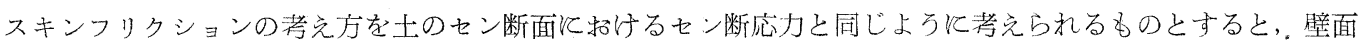
飞働く鈆直応力 $\sigma_{N}$ の下でスキンフリクション $F_{s}$ は（以下特别な表示以外スキンフリクションを $F_{s}$ と表わ す), $F_{s}=\sigma_{N} \cdot f+C_{A}$ (ここに $f$ : 摩摖係数, $C_{A}$ : 壁と土との付着力) で表わすことができる ${ }^{8}$ 。この $F_{s}$ は土と 壁体のいろいろな性質によつて変わるので, 簡単飞その因子をあげることはできないが, 上式中第一項は壁面粗

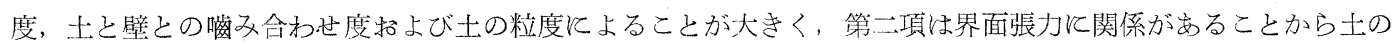
細粒分の多少と含水の状態が支配的なるのであることは知うれる。したがつて土の種類と壁面の粗度とが定皂れ 
表-1 摩擦軽減効果とそれを支配する因子の分類

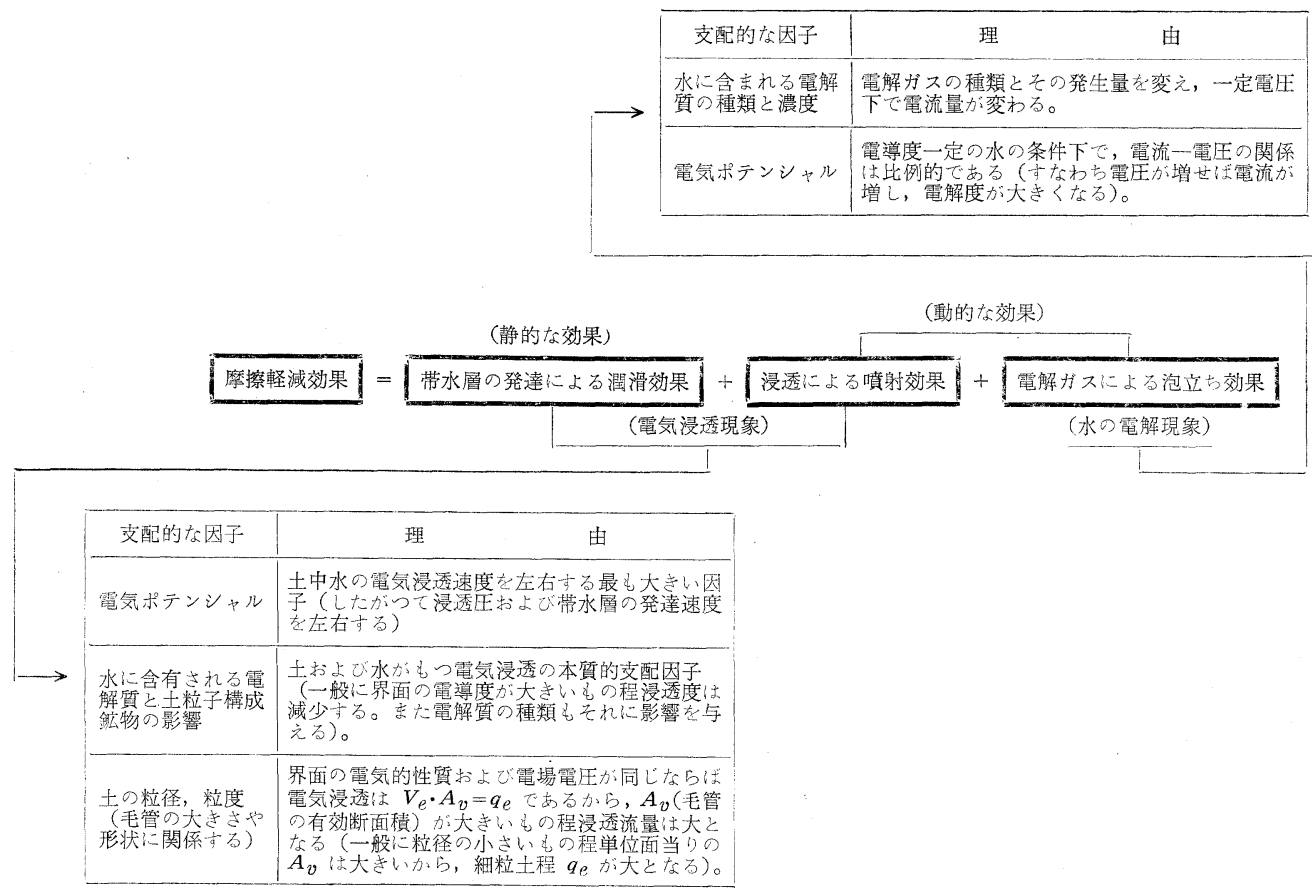

ば, 士の䋨委り度と含水状態が $F_{s}$ を左右する主因子と考光てさしつかえないことになる。これから述べる笑験で は, 結果の処理を容易にするため $F_{s} \fallingdotseq C_{A}$ なる条件を与兄るようにして $F_{s}$ 軽減の様相を考察することにした。

\section{(1) 実験の装置と方法}

(a) 装置の主な部分 図一1 K示すような装置で, 試料を詰める固定された箱（内径 $50 \mathrm{~mm}$, 高さ $30 \mathrm{~mm}$ のベイクライト円筒）と水平引き拔き板（試料端面に接して，水平に移動できるようにしたべイクライト板で， 試料接触面は鉄板が固定されるようにし 図一1 スキンフリクション測定装置

てまるとよりなる。

（b）載荷方法 付着力の平衡が破れ て水平引き抜き板が滑動し始めるまで一 定の荷重を一定時間ごとに段階的に加兑 ていく念力制御方式(5g の荷重を $30 \mathrm{sec}$ ごとに加えた）によつて土と鉄板との $F_{S}$ をはかるようにした。

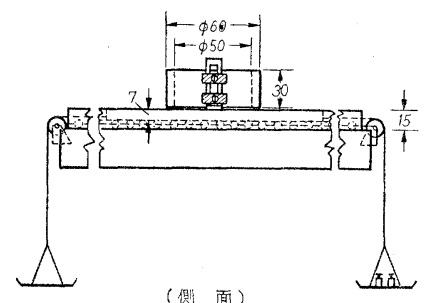

(c) $F_{s}$ 軽減回路 回路以图-5 (b) と同じもので, 電源飞恬 $12 \mathrm{~V}, 10 \mathrm{~A} \mathrm{hr}$ の堛電池索用い, 電圧調整用揩動抵抗器 は $1 \mathrm{~A}, 43 \Omega$ のものを並列に設けた。ま た電極は教料上端に炭素板を密接し，そ れを陽極として，鉄板を陰極とした（図 -1 (b) 参照)。

(d) 試料 用いた試料はすべて練り

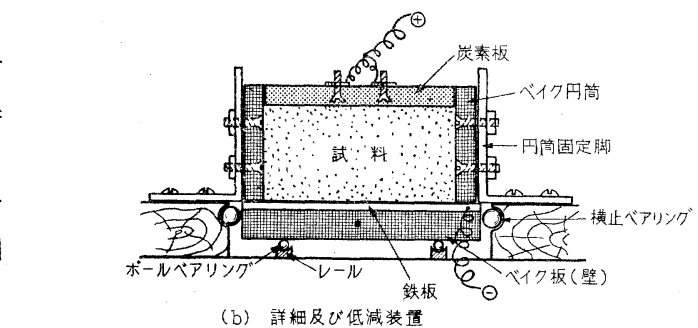

(b) 詳細及び低减装貫

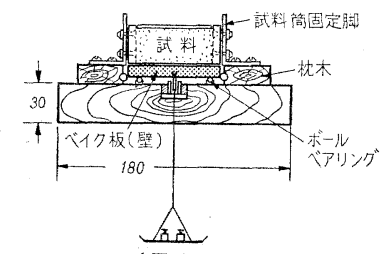
(a) 装置全体四 (正面)

返したもので, それの初期含水量は含水比変化の問題を検討する以外には，どの土に対しても液性限界試験器に よる叮数 30 回 (以後 $L L=30$ などの表示はこの意味) に相当する含水条件を与えた。添加電解質の影響をしら ベる場合には，純水の代りにいろいろな濃度の電解質溶液を用いた。また使用土は， $F_{s}$ 軽減の過程などを知る ための実験では埼玉粘士（ベントナイト系粘土）一種により，上の種類による効果の比較実験では，表一2 中に 示した数種のものを用いた。

(e) 試験方法 $F_{s}$ 軽減の時間過程括よびそれに影響する加電圧の大きさなどをしらべる実験では, 所定の 
表一2 $F_{s}$ 軽減効果を動的と静的に分離して検討するための実験結果

\begin{tabular}{|c|c|c|c|c|c|c|c|c|c|}
\hline $\begin{array}{l}\text { 䍿 料 } \\
\text { No. }\end{array}$ & $\begin{array}{l}\text { 試料に与えた条件お上び } \\
\text { 試料種類 }\end{array}$ & $\begin{array}{l}\text { 初期 } F_{s} \\
\pm と \text { 鉄板 } \\
\left(\mathrm{g} / \mathrm{cm}^{2}\right)\end{array}$ & $\begin{array}{l}\text { 通電時聞 } \\
(\mathrm{min})\end{array}$ & $\begin{array}{c}\text { 加霓王 } \\
\text { (V) }\end{array}$ & $(\mathrm{mA})^{\text {满 }}$ & $\begin{array}{l}\text { 全軽娍 } F_{S o} \\
\left(\mathrm{~g} / \mathrm{cm}^{2}\right)\end{array}$ & $\begin{array}{c}\text { 回路謈断後の } \\
F_{s c} \\
\left(\mathrm{~g} / \mathrm{cm}^{2}\right)\end{array}$ & $\begin{array}{c}\text { 動的効果 } \\
\left(F_{s o^{\prime}}-F_{s c^{\prime}}\right) \\
=F_{g^{\prime}}\end{array}$ & $F_{s c} / F_{s}{ }^{\prime}$ \\
\hline 1 & $\begin{array}{c}\text { 埼玉粘土と水道水 } \\
(w=99.66 \%)\end{array}$ & 8.17 & 0.42 & 4 & 89 & $\begin{array}{r}2.76 \\
(66.7)\end{array}$ & $\begin{array}{r}3.36 \\
(58.9)\end{array}$ & $\begin{array}{r}0.60 \\
(7.8)\end{array}$ & $(7.6)$ \\
\hline 2 & $\begin{array}{l}\text { 埼玉粘土 と } 2 \% \mathrm{KCl} \text { 液 } \\
(w=99.53 \%)\end{array}$ & 16.63 & 0.33 & 4 & 110 & $\begin{array}{r}5.53 \\
(66.8)\end{array}$ & $\begin{array}{r}6.43 \\
(61.4)\end{array}$ & $\begin{array}{r}0.90 \\
(5.4)\end{array}$ & $(11.3)$ \\
\hline 3 & $\begin{array}{c}\text { 埼玉粘士と你留水 } \\
(w=67.18 \%)\end{array}$ & 41.46 & 2.33 & 4 & 8.5 & $\begin{array}{r}16.58 \\
(60.1)\end{array}$ & $\begin{array}{r}28.59 \\
(31.0)\end{array}$ & $\begin{array}{l}12.01 \\
(29.1)\end{array}$ & $(1.1)$ \\
\hline 4 & $\begin{array}{c}\text { 埼玉粘土と蒸留水 } \\
(w=79.82 \%)\end{array}$ & 13.46 & 3.51 & 4 & 6.7 & $\begin{array}{r}3.87 \\
(71.3)\end{array}$ & $\begin{array}{r}6.81 \\
(49.0)\end{array}$ & $\begin{array}{r}2.94 \\
(22.3)\end{array}$ & $(2.2)$ \\
\hline 5 & $\begin{array}{l}\text { 東京ンルト質土と蒸留水 } \\
\quad(w=61.36 \%)\end{array}$ & 3.30 & 6.83 & 4 & 13.0 & $\begin{array}{r}1.11 \\
(66.7)\end{array}$ & $\begin{array}{r}2.61 \\
(21.2)\end{array}$ & $\begin{array}{r}1.50 \\
(45.5)\end{array}$ & $(0.5)$ \\
\hline 6 & $\begin{array}{c}\text { 関東口一公と蒸留水 } \\
(w=111.43 \%)\end{array}$ & 2.40 & 2.50 & 4 & 17.0 & $\begin{array}{r}1.11 \\
(54.1)\end{array}$ & $(21 .)^{1.71}$ & $\begin{array}{r}0.60 \\
(33.1)\end{array}$ & $(0,6)$ \\
\hline
\end{tabular}

(備栲) $F_{s o}{ }^{\prime}=F_{s}-F_{s o}$ (全軽減量), $F_{s c}{ }^{\prime}=F_{s}-F_{s c}$ (静的軽減最)

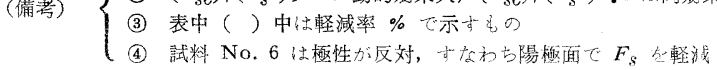

$F_{s}$ 量になるまでの時間をはかり，時間一軽減率 $\left(\frac{\left.\left(\text { 最初の } F_{s}\right) \text {-(安る時間たつたときの軽減 } F_{s}\right)}{\left(\text { 最初の } F_{s}\right)}\right)$ の関係を求わ るようにした。軽堿の動的効果と静的効果とを分離してそつ負担度を検討するための実験では, 初期の $F_{s}$ と全 軽減 $F_{s o}$ とをはかつた後, 回路を遮断したときの $F_{s c}$ とを注かり, 表一2 の要領で静, 動両効果を分離した。 いろいろの土に対する軽減効果の比較では, 初期 $F_{s} の 50 \%$ 軽減に要する時間をとつてそれを比較した。

\section{(2) 実験結果の考察}

（A）初期 $F_{s}$ の条件を含水量のみで変光，一定加電圧下でそれを軽減した場合の軽減過程之軽減範囲 一種

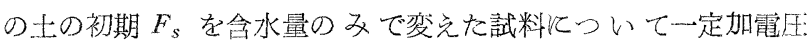
$(4 \mathrm{~V}) て ゙ F_{s}$ 軽減を行い，炎の軽減時間過程をしらべたのが図? 招よび 図一3である。

図から，士の界面条件が本質的飞変わるるのでなけれは，電気 浸透度は含水の多少年末り関係ないはずであり，しかも岁時 間通電していると最終 $F_{s o}$ は初期の条件に無関係に一定になる ことがわかる。これを軽減速度と最終軽減度の観点からすると， 電導度や浸透効果が通電初期には武料飽和度にいくらか影響され るので, 軽減速度も初期には多少とれが現われるが，軽減が淮㑕 するにしたがつてそれは全くなくなり，最終 $F_{s o}$ は一定となる。 これを初期 $F_{s}$ 飞対する軽減率で表わすと, 初期 $F_{s}$ 值の大きい るのが大きい軽減効果を示す法けである。図一3では最終 $F_{s o}$ の 軽減率が 65 95\% 飞達し, 10 分以内にそれが現われている。

(B) 土の初期 $F_{s}$ の条件が一定で，加電玨のみを变光た場合 の軽減度 試料の初期条件（一種の土で, 一定含水量）を一定と: 乙, 加電圧の夕 $4 \sim 6 \mathrm{~V}$ と変えて $F_{s}$ の軽減時間過程をしらべ たものを图 4 亿示した。加電圧の大小は，浸透と電解と共 飞左右する外的な因子であるから，一定武料条件飞対する軽減展 は去机よつて変わつてくることになる。

図一４亿上る之，試料条件が一定であれば，最終軽減率は加霞 压関係なく一定となるが，それに達するまでの時間過程が電压 汇よて変わるものであることを知る。

図一 2 初期 $F_{s}$ を含水で变え一定電圧 下で軽減した場合の時間過程

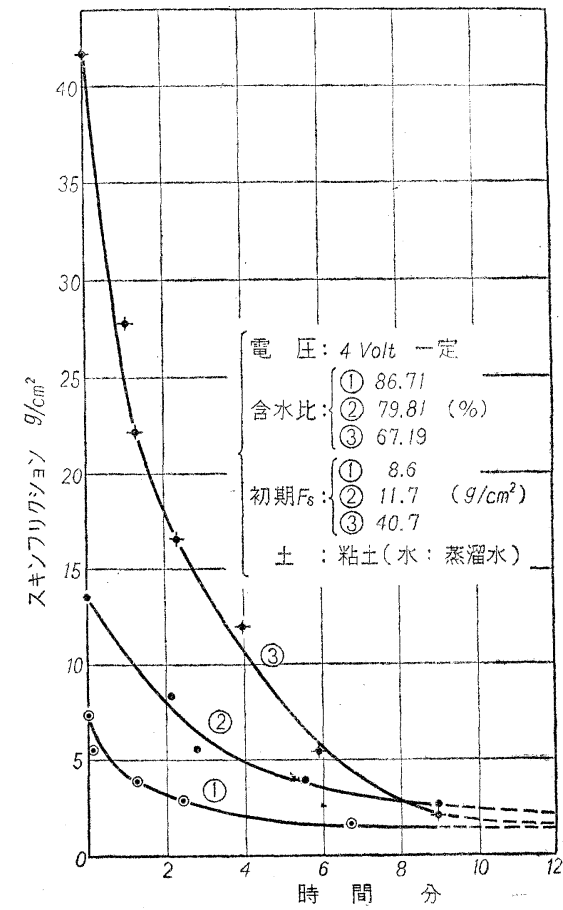

(A) と（B）で述べたことを総合して，士の初期 $F_{s}$ の差異は 最終軽減率に関係し，加電圧の大小は軽減速度に関係するものであるということができるり。

(C) $\boldsymbol{F}_{3}$ 軽減に招ける動的効果と静的効果の分離 表-1 で示したよろに全 $F_{s}$ 整減効果は, 静的なものと 動的な効果が複合されてのるのと考光られる。 
動的効果には浸透と電解の両者があ り、これらを分けて报うことはできな い。乙か乙全效果と静的効果とは, 通 電中の $F_{s o}$ と回路を遮断してからの $F_{s c}$ とがはかりうるので両 $F_{s}$ の差を とつて動的效果とすることができる。

表一2 は, いろいろの条件の試料保 つき加電圧 $4 \mathrm{~V}$ で軽減し，約 $1 / 3 F_{s}$ に 達するまでの時間をはかつて招き，そ の後回路を遮断してからの $F_{s c}$ をはか り $F_{s c}-F_{s} / 3=F_{s}{ }^{\prime}$ (動的効果) 求好雨 効果を分離し, さら $F_{s c} / F_{s}{ }^{\prime}$ (静的効 果との比）飞よつて両効果の負担度を 赤した。判然とした結論は，得られな

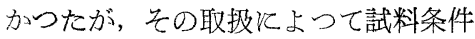
汶対し，いずれの効果が支配的である かの傾向は知ることができた。

（i）合水量が少なくて $F_{s}$ の大き いるの（同じ土で）では全軽減効果の ろち動的效果飞依存することが大きい ようである。

(ii）同程度の $F_{s}$ でも細粒土のほ ぞ $F_{s}$ 軽減効果は大きく, その效果は 静的なるのによがちで, 砂分の多い 土のほど動的効果によりがちである。
図一3 初期 $F_{s}$ を含水で变え一定電圧下で軽減した場合の時間 過程（ $F_{s}$ を初期 $F_{s o}$ 亿対する比で表わしたもの）

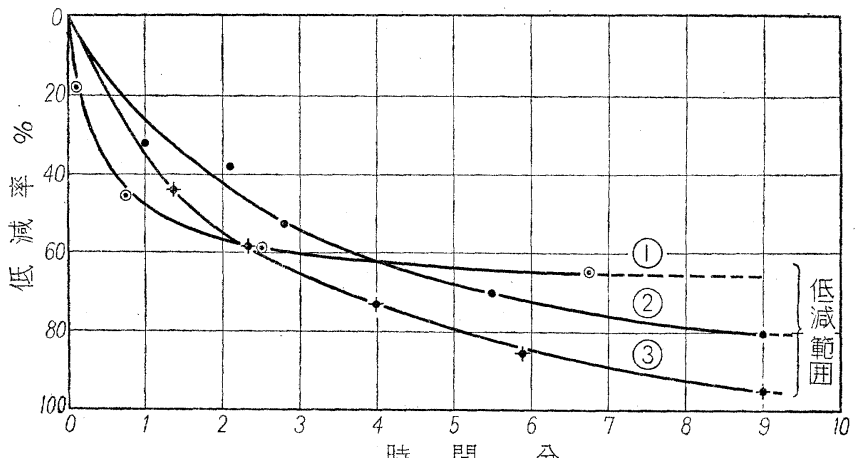

図一4 土および $F_{s}$ 条件を一定として加電圧を加えた 軽減時間過程

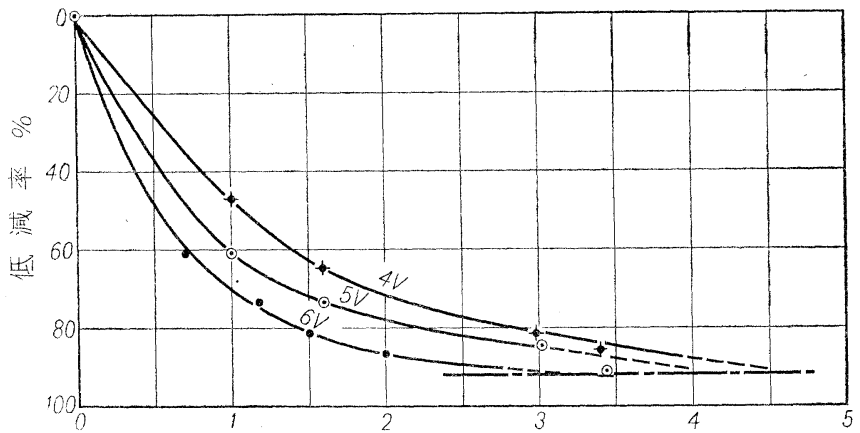

時間分

(iii）一般に軽減効果の低いものは動的効果に，高いるのは静的効果による傾向がある。

(D) いろいろな試料条件に対する軽減効果の比較 いますで述べてきたのは $F_{s}$ 軽減の基本的な様相を知る

表一3 いろいろの含有水条件と土の種類に対する軽減効果の比較

\begin{tabular}{|c|c|c|c|c|c|c|c|}
\hline 要因別分類 & $\begin{array}{l}\text { 傝 } \\
\text { No. }\end{array}$ & 採取場所と土の種類 & 含有水の条件 & $\begin{array}{c}\text { 含水比 } \\
(\%)\end{array}$ & $\begin{array}{l}\text { 初期 } F_{s} \\
\text { 土と鉄板 } \\
\frac{\left(\mathrm{g} / \mathrm{cm}^{2}\right)}{}\end{array}$ & $\begin{array}{c}\text { 電流密度 } \\
\text { (mA) }\end{array}$ & $\begin{array}{c}F_{g} \text { を } 50 \% \text { 軽減 } \\
\text { するに要した時間 } \\
\text { (sec) }\end{array}$ \\
\hline \multirow{3}{*}{$\begin{array}{l}\text { 土の含水に } \\
\text { よる啘硬 } \\
\text { (I) }\end{array}$} & $I-1$ & ボーリンク用粘士 & 水 道 水 & 38.5 & 9.93 & 9 & 5 \\
\hline & $I-2$ & " & $"$ & 40.0 & 9.67 & 12 & 9 \\
\hline & $I-3$ & " & $"$ & 42.6 & 8.66 & 14 & 10 \\
\hline \multirow{8}{*}{$\begin{array}{l}\text { 含有水の電 } \\
\text { 解質濃度之 } \\
\text { 哈水量の変 } \\
\text { 化 } \\
\text { (II) }\end{array}$} & II -1 & ボーリング用粘土 & \multirow{2}{*}{$2 \% \quad \mathrm{NaCl}$} & 44.7 & 11.54 & 43 & 75 \\
\hline & II -2 & $"$ & & 45.6 & 7.97 & 45 & 60 \\
\hline & II -3 & " & \multirow{2}{*}{$3 \% \quad \mathrm{NaCl}$} & 42.7 & 11.00 & 38 & 70 \\
\hline & II -4 & " & & 47.3 & 8.24 & 49 & 50 \\
\hline & II -5 & "s & \multirow{2}{*}{$5 \% \quad \mathrm{NaCl}$} & 38.1 & 12.08 & 59 & 130 \\
\hline & II -6 & " & & 42.3 & 9.34 & 57 & 100 \\
\hline & II -7 & " & \multirow{2}{*}{$6 \%$} & 39.4 & 15.37 & 50 & 151 \\
\hline & II -8 & $"$ & & 44,8 & 9.91 & 59 & 75 \\
\hline \multirow{10}{*}{$\begin{array}{l}\text { 種々の自然 } \\
\text { 土を用いた } \\
\text { 楯類別 } \\
\text { (III) }\end{array}$} & III -1 & 埼玉粘土 & 水 道 水 & 99.7 & 8.17 & 89 & 25 \\
\hline & $\pi I I-2$ & 兟木田ローム & $"$ & 40.4 & 4.95 & 5 & 15 \\
\hline & III -3 & 杤木（日光）粘土ローム & " & 29.7 & 5.49 & 6 & 20 \\
\hline & III -4 & 小茶の水ローム & " & 38.0 & 5.77 & 11 & 14 \\
\hline & III -5 & . " " & " & 40.0 & 5.49 & 10 & 14 \\
\hline & III -6 & 東京沖積土（シルト質土） & $"$ & 37.9 & 9.62 & 11 & 4 \\
\hline & III -7 & " & $"$ & 40.7 & 7.68 & 10 & 4 \\
\hline & III -8 & 真室川粘土室ローム* & $"$ & 63.5 & 4.95 & 8 & 330 \\
\hline & III -9 & 寺島粘土 & $"$ & 57.4 & 5.77 & 18 & 8 \\
\hline & III -10 & 練馬関東ローム & $"$ & 114.7 & 2.40 & 17 & 150 \\
\hline
\end{tabular}


ためのものであつたが，試料条件はごく単純なものであつたので，ここでは含有水の電解質条件をさらに細かく 変えたり, 土も自然のものを多く選んで, それぞれの軽減効果を比較してみた。表一3 中, 試料 No. 1〜4 અ電 解質の影響をしらべるために一種の粘土に濃度を変えた $\mathrm{NaCl}$ 溶液を加わ元た試料について行つた効果の比較を 示すものであるが，それによると添加電解質濃度の大きくなる程軽隇効果が低くなつていく傾向があることが知 られる。しかし 2 3\% 以下の濃度ではそれがいちじるしく低減されるものでない。

試料 No. 5〜10 はいるいるな自然土の効果を比較して, 土にょる選択性を検討してみたものである。それに よると，岁る種の土は軽減効果のきわめて低いものがあることがわかる。一般灿灰質土とがかなり多量の石

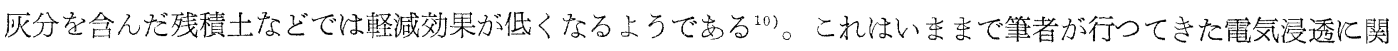
する一連の実験でも知られた現象で, その種の鉱物成分の土は, 低い界面動電位を有するためと考学ることがで きる。

\section{IV. ウエルやパイプ沈設の模型実験}

$F_{s}$ 軽減の機構を基本的に知つたので，これを応用する㴔味でウェルなどの沈設英験を模型的飞行つた。

\section{(1) 実験方法と実験計画}

(a) 装置 模型実験では 図一5 (b) に示すようなガラス槽 $(20 \times 20 \times 25 \mathrm{~cm})$ 飞試料を詰めた。また沈設す ベき模型ウエルとして, 内径 $75 \mathrm{~mm}$, 肉厚 $2.5 \mathrm{~mm}$ の真输パイプ（長さ $150 \mathrm{~mm}$ とし，貫入側の先端を刃先に なるようと加工したもの）を用いた。

陽極隹電蝕の影響の少ないグラファイト棒（径 6 $\mathrm{mm}$, 長さ $150 \mathrm{~mm}$ の) を用い, ウエルを陰極とした。

回路は図一5（a）に示すようなもので11)，電源は $30 \mathrm{~V}, 18 \mathrm{Ahr} の$ 蓄電池汇よつた。京た図中, スイッチ そ極コントロールと変換スイッチとを設けたのは，使 用陽極の任意選択と必要江応じて極性を反転交換する ためのものである。

(b) 奏験方法 パイプの沈設実験では， $F_{s}$ 軽減 をはかる前にあらかじめ $3 \mathrm{~cm}$ 程度静荷重によつて沈 めて招き，それが平衡するときの荷重 $W$ を記録して から，弪れを 0.5〜1.0 kg 残して他を取り去り，しか

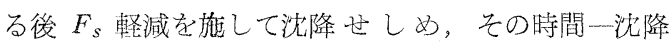
を記録した。李た試験前の単位 $F_{s}$ を求めるのと径 $6 \mathrm{~mm}$ の鉄棒老所定の深さ $(10 \mathrm{~cm})$ 飞挿入し, それ を引き拔くようにした。

(c) 試料 実験に用いた試料は, 試料の硬さに上 る影響をしらべるためのもの以外には, 試料の一様性 を保ちやすくすること，飽和に近いるのとするとと掠 よび $F_{s} \fallingdotseq C_{A}$ の条件を与光て 解析を容易泟すること のために $L L$ テスターによつて 150 回叮数程度とな るようにコンシステンシーを管理した。また土は䊀度

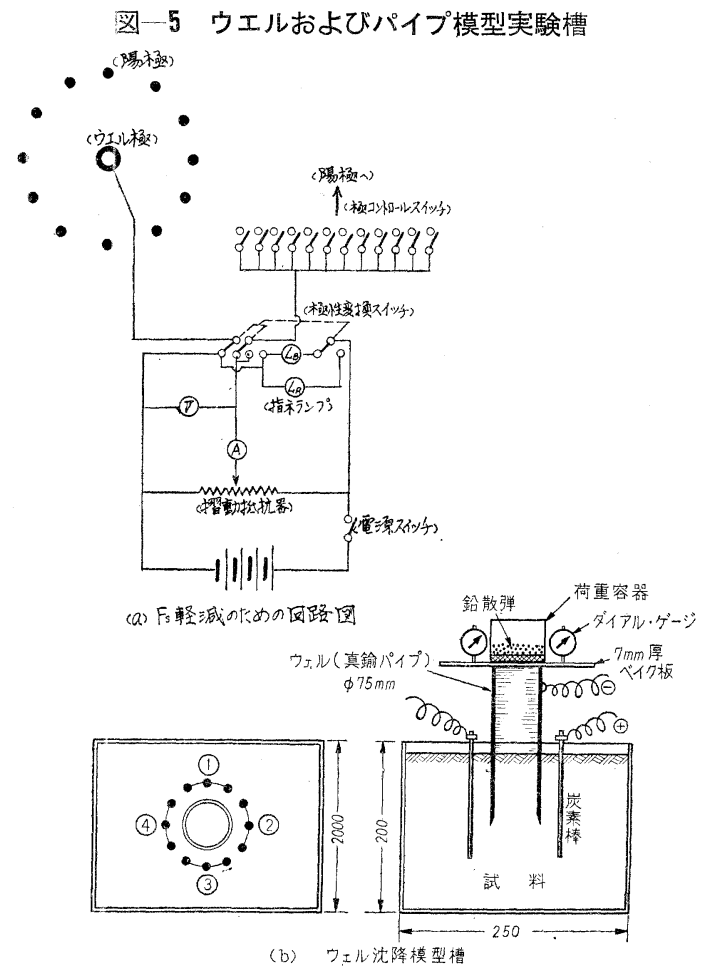
による影響を検詰する目的以外は粘土一種を用いた。

電解質の影響をしらべる場合には，同じ粘士に規定の $\mathrm{NaCl}$ を加え，それを試料とした。

(d) 実験計画 予備実験てて $F_{s}$ 軽減の支配因子が何であるかを大体知つたので，模型実験でもとれを考慮 して行つた。表一4 は本実験で行う要因別の「わりつけ」をまとめて揭げたものである。

\section{(2) 実験結果の考察}

（A）模型ウ土ルの沈降の様相 II で $F_{s}$ 軽減の原理を述べたが，この原理がウエル沈設などの場合にも同じ ようと考光られるとすると, 図一6亿示したような $F_{s}$ 䎦減の様相が想像できる。

図一7は，時間一沈降の関係から， $F_{s}$ 軽減によつて沈降がごのように起こるかを知るために，静荷重のみで 沈降せしめたものと比較した。図から知られるように $1 \mathrm{~V} / \mathrm{cm}$ 程度の霓压勾配を与光ただけで， $F_{S}$ の大部分が 軽減されるものであることが知られる。一方 $F_{s}$ 固結を施したものでは，それが永久的でないにしても $F_{s} は$ なり大きくなる。 
表一4 $\quad F_{s}$ 軽減を支配する主な因子の分類と実験の「わりつけ」

\begin{tabular}{|c|c|c|c|c|c|c|}
\hline & 含水 比 $(\%)$ & $\begin{array}{l}\text { 砂配合率 } \\
(\%) \text { ( }\end{array}$ & $\begin{array}{l}\text { 添加した } \\
\mathrm{NaCl} \text { の濃 } \\
\text { 度 }(\%) \\
\end{array}$ & 加電圧 $(\mathrm{V})$ & 陽 極 本 数 & $\begin{array}{l}\text { 雨極間距 } \\
\text { 離 } \\
(\mathrm{m}) \\
\end{array}$ \\
\hline $\begin{array}{l}\text { 含水量のみで初期 } \\
F_{s} \text { を変えた試料条 } \\
\text { 件 }\end{array}$ & $\begin{array}{l}42.5(L L=100 \text { 回 }) \\
40.2 \text { ( } L L=150 \text { 回 }) \\
32.8 \text { ( } L L=300 \text { 回 })\end{array}$ & $\begin{array}{c}0 \\
\text { (粘土のみ) }\end{array}$ & $\begin{array}{c}0 \\
\text { (水道水) }\end{array}$ & $\begin{array}{c}\text { 各試料につき } \\
\left\{\begin{array}{l}3.0 \\
3.5 \\
4.0 \\
4.5\end{array}\right\}\end{array}$ & $\left\{\begin{array}{r}\text { ウエル外 } 12 \text { 本 } \\
\Rightarrow \text { 内 } 1 \text { 本 }\end{array}\right.$ & 3.0 \\
\hline $\begin{array}{l}\text { (粘土)+(砂) の配 } \\
\text { 合率を変えて作つた } \\
\text { 試料条件 }\end{array}$ & $\begin{array}{c}40.2 \\
34.0 \\
28.6 \\
40.2 \\
\text { (各 } L L \fallingdotseq 150 \text { 回) }\end{array}$ & $\begin{array}{r}0 \\
20 \\
40 \\
60\end{array}$ & $\begin{array}{c}0 \\
\text { (水道水) }\end{array}$ & $\begin{array}{c}\text { 各試料につき } \\
\left\{\begin{array}{l}3.0 \\
4.0 \\
5.0\end{array}\right\}\end{array}$ & 同上 & 同 上 \\
\hline $\begin{array}{l}\text { 添加電解質の水分量 } \\
\text { に対する含有率を変 } \\
\text { えた試料条件 }\end{array}$ & $\begin{array}{c}40.2 \\
39.7 \\
40.5 \\
45.3 \\
46.2 \\
\text { (各 } L L \fallingdotseq 150 \text { 回) } \\
\end{array}$ & $\begin{array}{c}0 \\
\text { (粘土のみ） }\end{array}$ & $\begin{array}{l}0 \\
2 \\
3 \\
5 \\
6\end{array}$ & $\begin{array}{c}\text { 各試料につさ } \\
\left\{\begin{array}{l}3.0 \\
4.0 \\
5.0\end{array}\right\}\end{array}$ & 同上 & 同 上 \\
\hline $\begin{array}{l}\text { 加電圧の大きさが沈 } \\
\text { 降速におよばす影響 }\end{array}$ & - & - & - & $\begin{array}{l}\text { 上記条件の試 } \\
\text { 料についての } \\
\text { 総合比較 }\end{array}$ & 同上 & 同 上 \\
\hline $\begin{array}{l}\text { 陽極本数による沈降 } \\
\text { の変化と最小必要本 } \\
\text { 数 }\end{array}$ & $42.5(L L=100)$ & $\begin{array}{c}0 \\
\text { (粘土のみ) }\end{array}$ & $\begin{array}{c}0 \\
\text { （水道水） }\end{array}$ & 4.0 & $\begin{array}{r}3 \\
4 \\
6 \\
8 \\
12\end{array}$ & 同 上 \\
\hline $\begin{array}{l}\text { 両極間の位置と電圧 } \\
\text { 勾配との問題 }\end{array}$ & 同上 & 同上 & 同 上 & $\begin{array}{l}\text { 電圧勾配 } \\
2.0(1.0) \\
3.0(1.0) \\
5.0(1.0)\end{array}$ & 4 & $\begin{array}{l}2 \\
3 \\
5\end{array}$ \\
\hline
\end{tabular}

註）表中 $L L$ とは $L L$ テス夕ーによる打撃数を示し，土の軟さの状態をそれで管理した。 要因の中土の種類別は模型実験では取り扱はなからた。

図一7 同じ試料条件で $\boldsymbol{F}_{s}$ を軽減した場合, しない場合および周辺固結した場合の 沈降状況の比較

図一6 $\boldsymbol{F}_{s}$ 軽減機構を示した原理想像図 荷 重

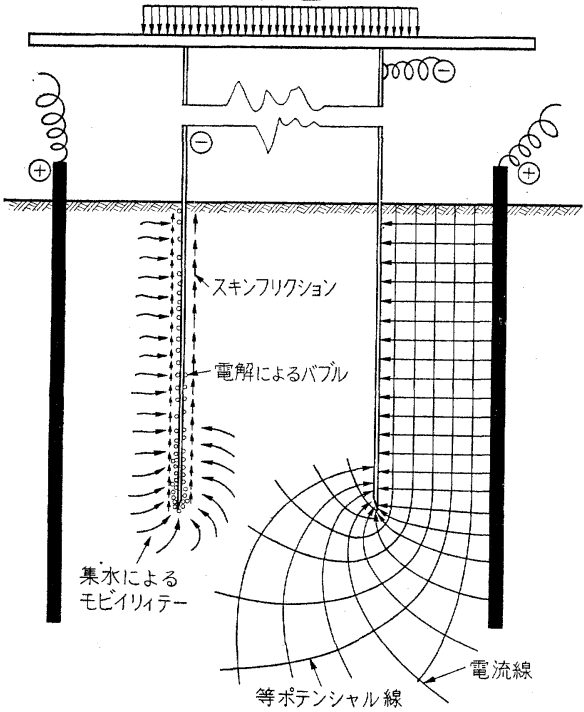

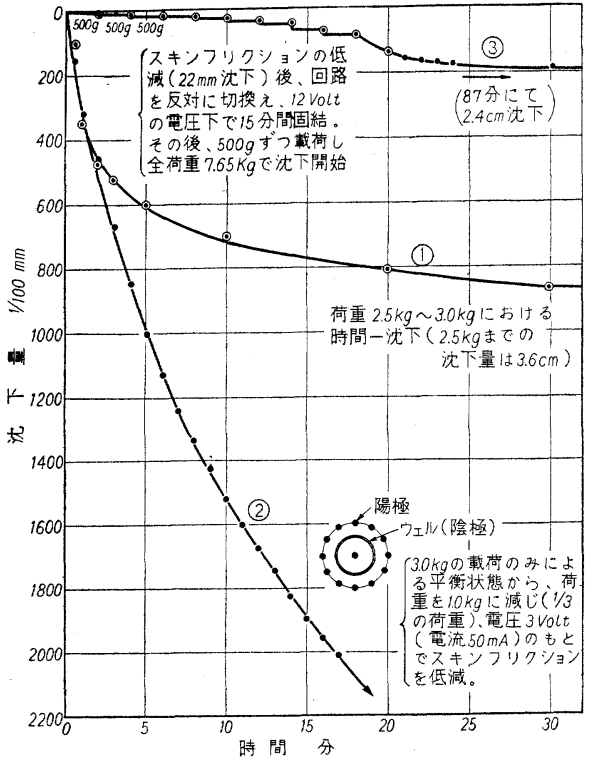

(B) 含水量の多少で試料の硬さを変えた場合の沈降 初期 $F_{s}$ を含水量の多少のみで变化せしめ，かつ $F_{s} \fallingdotseq$ $C_{A}$ の条件を与兄るようにした試料を用いて，土のコンシステンシーが沈降に抽よぼす影響をしらべたるのが図 -8である。図によると，低い加電圧条件下では試料の軟硬が沈降にかなり影響するものであるが，加電圧を大 
図一8 土の軟さによる沈降の比較

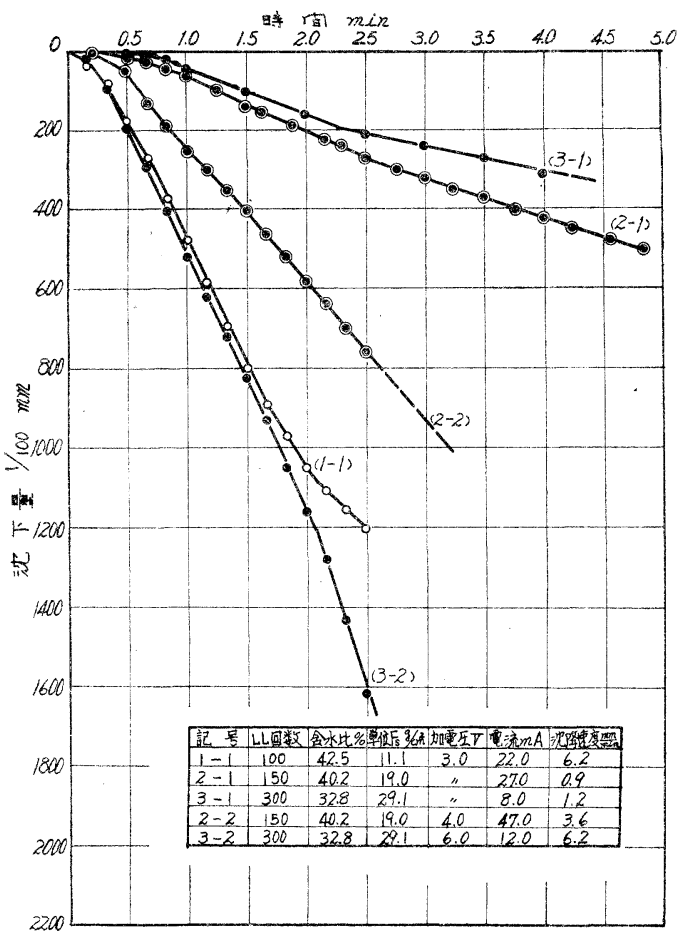

図 -9 砂の配合率を変えて作つた試料の粒度別沈降比較



きくすると，去の影签はほとんどなくなる。

例觉ば，図一8，(3-1) と（1-1）の曲線とを比較するに 単位 $F_{s}$ が 2 倍程度大きくなる硬さでさえも，平均 速度は $1 / 5$ となり, 硬さが (電圧が低い場合) いちじるしく影響してくることがわかる。また単位 $F_{s}$ が大きく なつても加電圧を 2 倍位大きくすると，沈降速度は 5 倍も憎することが (3-1) 亿対し (3-2) をみれば知られ， 加電圧が $F_{s}$ 軽減飞支配的な因子となるものであることがわかる。

(C) 粘土と仯の配合率を変兄て作つた試料の粒度によ吕影響 土の種類を単純に粒度のみで変わるとして， 配合率を変光た試料を作り，砂混入率が $F_{s}$ 軽減に招よほすす影響をしらべた。

図一に示す結果は，どの配合のもの子硬さの程度を一様となるようにした試料について行つた実験であるが この実験結果による限りでは，砂分が多くても軟さが一様であれば， $F_{s}$ 軽減には粒度の影響は考克なくてもよ いと思われる。結局土の種類として考兄る必要のあるととは土粒子構成鉿物招よび水の界面としての性質の差異 であつて，粒度は $F_{s}$ 軽減に本質的な影響を与兄るものでないと考光てさしつか觉ないようである。

しかし一般には, 砂分の多い土は固結度も大きく，委た電気浸透的効果が水理的逆流炕つて少なくなる傾问 があるので ${ }^{12)}, F_{s}$ 軽減効果はそれらの理由で低下する。

(D) 電解質の濃度による影響 自然土の含有する電解質の種類や濃度は堆積されているところによつてさま

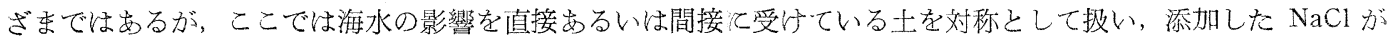

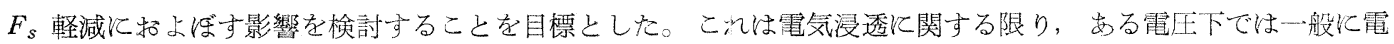
解質の濃度の高い程浸透度が減ずるものであることが知られているので ${ }^{13)}$, その影響を $F_{s}$ 軽減についてしらべ

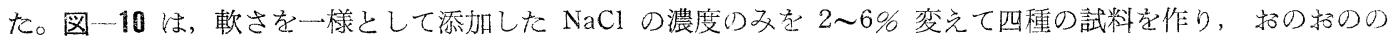
試料について 3〜 $5 \mathrm{~V}$ まで電圧を変えて行つた実験である。その結果によると， $F_{s}$ 軽減効果が電気浸透のみに よらないで, 電解効果が条件によつてはかなり大きい軽減原因となることが知られる。例えば $3.0 \mathrm{~V}$ の電圧下で は $2 \% \mathrm{NaCl}$ よりる $5 \%, 6 \% \mathrm{NaCl}$ の方が大きい沈降速度を示している。加電圧を大きくすると, 電解質の影 響はほとんど現われないようである。

(E) 加電圧と平均沈降速度 加電庄の大小性， $F_{s}$ 軽減を支配する外的因子として最も大きいものであるか ら，土の条件が定末つたものでは，それが沈降速度を左右する主な原因となる。いままで述べてきたいろいるの 条件別実験結果を一括して, 加電圧と平均沈降速度の関係をとつてみると図一11 のようになる。図一11 から 考察できることは, ある加電圧を超す電圧を与兄ると, どの陚料条件の場合も平均沈降速度は電圧の増加によつ 
図一10＼cjkstart液の電解質濃度の影響をしらべる ための比較

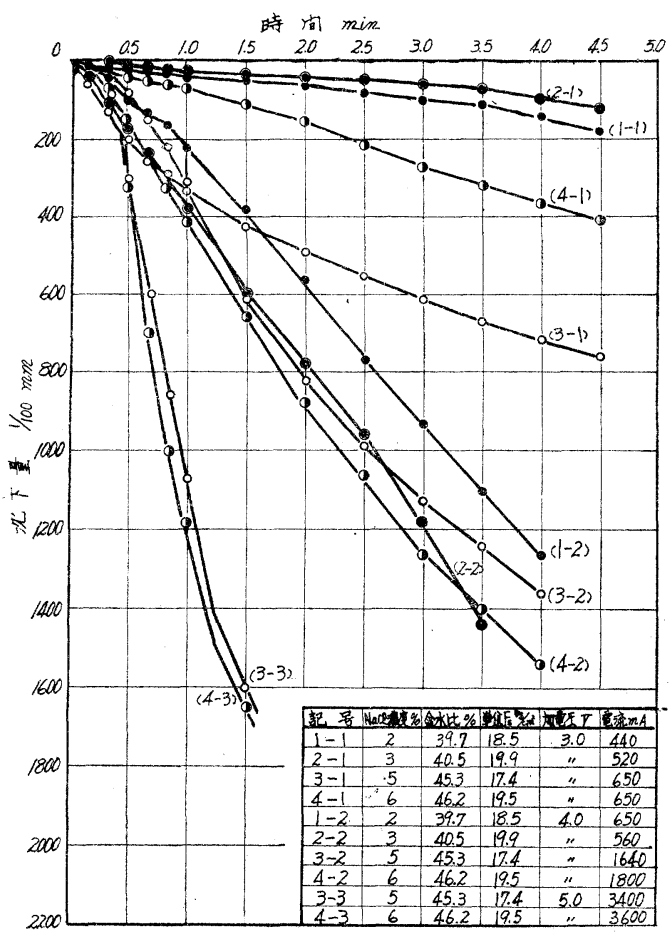

図一11 いろいろな条件の試料についての 加電圧一平均沈降速度の関係

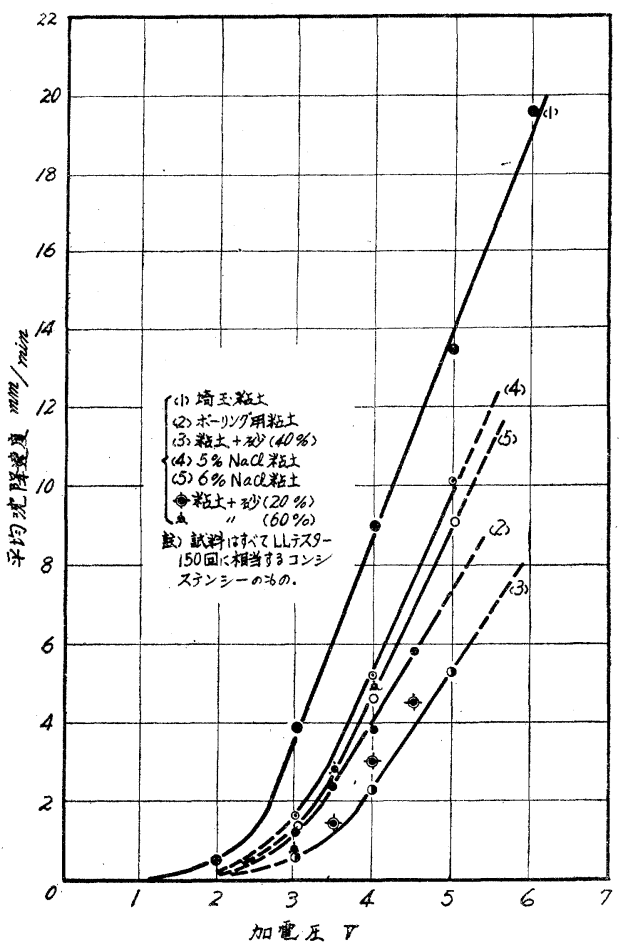

て直線的に增すといろことである。

末たそれらの結果が, 情報することは, 試料条件は電圧一沈降速度関係の位置を変化させるだけのものであつ て，ある加電圧以上の電圧下では軽減効果にあまり大きい影響を与えるるのでない，ことが知られる。

総合してい党ることは，外的と加える電圧の調節だけで沈降速度を変化させることができるということと，電 圧さえ大きくすれば陚料条件の影響は減殺できるということである。

(F) 陽極配列之電極間距離住関する電極設置上 の問題 本法の実施で, 経済性と設置計面の面から 電極位置の決定は重要なととである。その効果と影 響とをしらべるためと陽極の挿入深度, 本数招よび 間隔などいろいろ変えて実験したのが 図一12 亿示 すものである。

図中破線で示した曲線（I-1)〜 ( I - 3) は，見掛 けの電圧勾配を一様とした場合の結果である。ここ でいう見掛けの電生勾配とは, 電極間距離沉応じて $1 \mathrm{~V} / \mathrm{cm}$ （一定）となるよろな電压を与えたという意 味（例兑价電極間距離 $2 \mathrm{~cm}$ 場合は加電圧 $2 \mathrm{~V}$ ) で ある。その結果によると, 沈降速度は加電圧の絶対 值の大きいものが大きく，それに対し，距離はあま り問題とならない。一方陽極本数は, 多くなる程効 果は增すが, 極本数が 3 倍となつても速度はせいぜ い1.8 倍程度しか増さない。

結局陽極本数を多くするよりも加電圧でそれを補 うようとする方が経済的でもめり，4 本以上ならば 特に本数を問題にするとたらない。陽極深さは少な

図一12 陽極本数とそれの設置条件をしらべるための比較

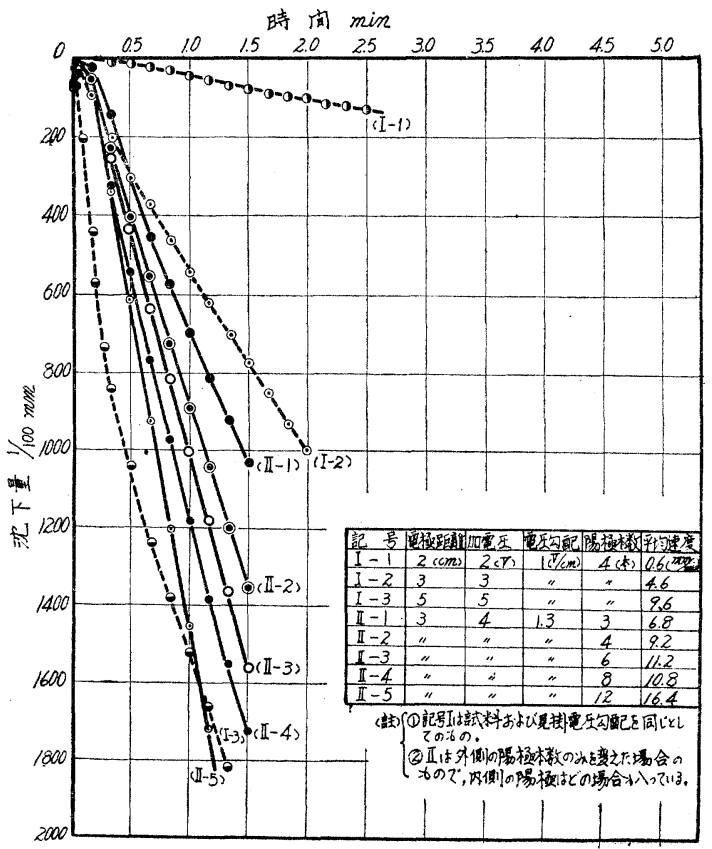


（G）曲進回復法としての適用 ウェル沈設中地層の不整形や荷重の偏心など そよつてウェルが曲進していくことがしばしばある。ここではその種の曲進が起 り始めたとき亿， $F_{s}$ 軽減方法を变光，それを回復させる上うに同じ電気回路を 用いて行万場合について述べる。曲進がいまだ大きくないときには, 図一13 に 示すような $F_{s}$ の場所的変化を与兄る手段をとれ海回復できるわけであるから， それを与兄るような方法すなわち $F_{S}$ の増減を極性のみの交互変換を行うことに よつて実現できる。図に示すものは, あらかじめ $6^{\circ}$ の傾きを与兄て招いたウェ ルの回復実験の一例であるが，この実験では電圧 $15 \mathrm{~V}$ を加電したもとで行い, 1 分間ずつのスイチコントロールによつて固結と軽減を交互に繰り返し，もとの 状態から $8.8 \mathrm{~cm}$ の沈降によつて回復できた。

この方法の応用は, 実際にそれを行う抬とする場合, かなりむずかしいことで あろうが，方法としての可能性は十分ある。

(H) 沈設後の周辺土固結 埋設物は沈設が終れば周辺の $F_{s}$ が大きくなる程 抵抗が増すから，軽減の逆手段を用いて $F_{s}$ を増すととが望をしいわけである。 それを実現するには，沈設完了と同時飞回路を反転して，電気浸透的固結を行つ

図一13曲進回復の実験図
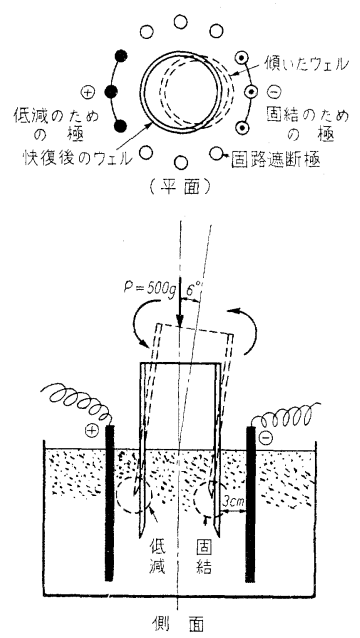
てやればよいこととなる。しかし 図一14 からも知られるようと水の復元のため この種の固結は， $F_{s}$ 増加の意味からは 一時的な效果を与光るだけで，永久的な ものとはならない。それ市固結による $F_{s}$ 増加は.せぜい元の $F_{s}$ 程度しか期 待できず，あまり，重要な意味をもたな いこととなる。

しかしながら周辺土を固結することは 上述の理由の他に周辺土の圧密促進とい う重要な現象を伴うはずである。この短 時間飞生ずる圧密は, 施工後長い時間を 経て起りらるネガティブフリクションの 影響を軽微㲸するはずで, 構造物の安定 を事前に大きくして括くという意義をる つ。

ネガテイブフリクションに関する実験 は行つていないが, 将来その問題も取り 扱つてみるつるりである。

図一14 周辺土を固結して放置した場合の $\boldsymbol{F}_{s}$ 低減状況

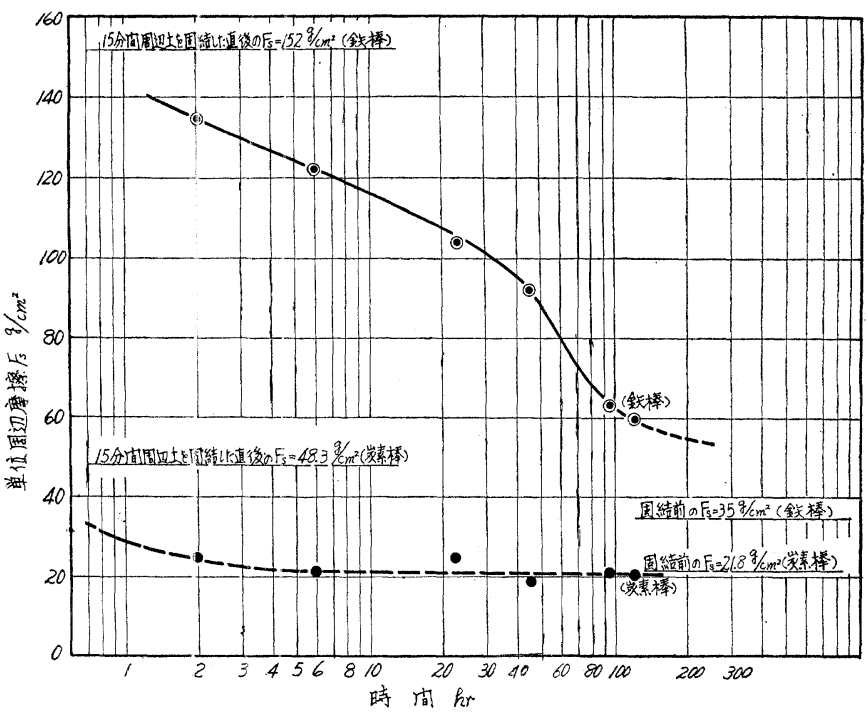

\section{Begemann の研究に対する 2,3 の討議15)}

Begemann の行つた実験は，それが野外飞扔ける実物大のものであつたという点では実際的かつ有用な研究で はあるが， $F_{s}$ 軽減の基本的な考方方に問題とされる点があるように思う。そこで軽減機構や土に対する適性の 問題をあげ，筆者の考光と対比してみた。

\section{(1) $F_{s}$ 軽減の原理について}

Begemann は $F_{s}$ 軽減が壁面でぞんな状態で起こるかの考察を除き「粘土に挿入した二本の金属棒を直流電 源の陰，陽にそれぞれ接続したとき，陽極の棒は固くくつつき，反対汇陰極の棒は 1 3 分で, それを引き抜く に要する力が非常に少なくてすむ」といつた結果的な現象のみをもつて原理としている。筆者の提案も想定の域 を出たものではないが，電気浸透と電解の概念を搪張し，いろいろの基本実験でそれを裏付けたので，考光方に 大きな誤りはないと思う。 $F_{s}$ 軽減の機構をよりょく解していないと本法適用と大きい限定をうける。

\section{(2) 室内実験結果の考察について}

Begemann は挿入深さ $50 \mathrm{~cm}$ の金属棒を電流適用時間ごとに引き抜き，各時間ごとの最大 $F_{s}$ を求め, 次の ような考察を行つている。

加電を 5 分以上続けると通電によつて逆に $F_{s}$ 軽減効果がドロップしていく傾向があるととを指摘している。 そしてその原因が，簡単に電気一物理的効果によるものであろうと述べている。 
$F_{s}$ 軽減が電気浸透のみによつて起こるとすると，たしかに通電時間によつて浸透が低減されていくすのがあ るが (一定電圧下では継続通電によつて電流密度が減ずるため) $\left.{ }^{16}\right), F_{s}$ 軽減に関する実験では, その現象は認め られなかつた。これは浸透の軽減のみが原因でないためと思う。

またこの現象を除く方法 ( $F_{s}$ 軽減勃果を維持する方法として) として Begemann は swich and cut off を繰 り返すと効果的であるとしているが，これは有効な手段であることは別の実験で筆者も認めた 作が有効であることの理由には触れていない ${ }^{18)}$ 。

\section{VI. 結 言}

以上は， $F_{s}$ 軽減法として直流電流の適用による方法が可能であることを指摘し，いろいろな条件についての 実験を行い，各項を遂一検討した。与文条件が理想的に過ぎることと小規模な実験結果の考察という点から実 用するにはいぬだ多くの検討を要するものであるが，この方法が，ウエルの沈設，矢板引き抜き，鋼パイプの挿 入, 特よびそれの引き抜き等の実施に当つて $F_{s}$ 軽減の手段として用いろるものであることは予想できる。

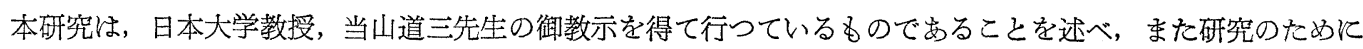
多大な援助を与え下さつている先生の御厚情に対し深謝の意を表する。

本学土木工学科学生, 中川 茂, 荒木和彦, 武藤隼彦の三君には実験招よび整理で多大な学を負わせた。また 梶谷調査工事 K K，梶谷正孝氏の協力を受けることができた。ここで各位に御礼申し上げる。

この一文を故巻内一夫先生の霊前に捧げる。

\section{参考文献 その他}

1) 浅川美利：“電気浸透法を用いたスキンフリクンョンの低減”, 日大工学研究所稞報 No. 17, pp 1 17 (1958)

2)，3）最上武雄: “土質力学”, pp. 145 149

4) H.K.S. Ph. Begemann: "The Influence of a Direct Current Potential on the Adhesion between Clay and Metal Objects", Proc. 3rd Int. Conf. on Soil Mech. \& Found. Eng. Vol. 1, pp. 89 93 (1953)

5）例えば，(1) 浅川：“土中水の電気浸透的流動および脱水過程について”, 日大工学研究所異 No. 19, pp.1 21 (1959)

(11) H.F. Winterkorn: "Foundamental Similarities Between Electro-Osmotic \& Thermal-Osmotic Phenomena", Proc. Highway Res. Board, Vol. 27, pp. 443 455 (1947)

6) (1) 同上, (iil) E. Vey : “The Mechanics of Soil Consolidation by Electro-Osmosis", Proc. Highway Research Board, pp.578 589 (1949), (四 三瀨 貞：土木学会 33 年度年次講演会概要 “土の電気漫透的脱水”, (10 M.G. Spangler \& H.L. King : Electrical Harding of Clays Adjacent to Aluminum Friction Piles”, Proc. Highway Resea. Board, Vol. 29, pp. 589 599 (1949)

7) 例之ば, 駒形作次：界面電気化学概要，pp.60〜63，あるいは L. Casagrande : “Electro-Osmotic Stabilization of Soils”, Jour. Boston Soc. Civil Eng. Vol. I, pp.51 83 (1952), or Proc. of the Conf. on Soil stabili. M.I.T (1952)

8）最上武雄：“土貿力学”, pp.145 149, 最上, 水野：東大理工研報告 Vol. 3 (1949) および文献 1) pp.1〜6

9) 詳細は交献 1) pp.7〜9

10）森 鏻：土木学会誌 Vol. 37, No. 11, pp. 13 17, 浅川：文献 1）pp 8９ と土と基碟 Vol. 6, No. 5 pp.28〜31 (1958)

11）文献 1） p. 9 に示すものを改良した装置

12) 駒形作次: “界面電気化学概要”, p.75

13）同上 pp. 28 36 あるいは 加藤二郎：“界面電界”, pp 32 33

14）文献 1) p. 13 に「陽極插入深さについてのいるいるな場合」を述へている。

15) 文献 4) の中 pp.89 90の Laboratory test について

16)，17）文献 5）に継続通電の影響を実験的に検討し，詳説してある。

18）電流密度の減少は，例えば「イオン雲の発生による（志方氏の思想）あるいは「コンデンサー効果」とかの原因によると考える。

(昭. 34. 1.26) 